\title{
Quantification of toxic metals during different winemaking stages
}

\author{
G.-D. Dumitriu (Gabur) ${ }^{1}$, C. Teodosiu ${ }^{1}$, I. Morosanu ${ }^{1}$, O. Jitar ${ }^{1}$, and V.V. Cotea ${ }^{2}$ \\ 1 "Gheorghe Asachi" Technical University of Iasi, Department of Environmental Engineering and Management, Romania \\ 2 "Ion Ionescu de la Brad" University of Agricultural Sciences and Veterinary Medicine of Iasi, Department of Viticulture and \\ Oenology, Romania
}

\begin{abstract}
Heavy metals in beverages can constitute serious problems to human health. Consumption of wine may contribute to the daily dietary intake of pollutants, especially of toxic (heavy) metals. These compounds are also known as priority pollutants due to their potential toxic effects, if concentrations are not kept under allowable limits. Many characteristics such as: quality, origin, aroma and health safety of wine are influenced by environmental and anthropogenic factors. Hence, the contamination of wine by priority pollutants may occur at different stages of vine-growing, due to the application of agricultural chemicals, or at different stage of winemaking and ageing, because of the extended contact of wine with winemaking equipment materials (aluminium, brass, glass, stainless steel and wood, etc.), or chemicals used for cleaning and sanitation. The aim of this study is to identify and quantify the heavy metal ions from red wines. A particular focus was attributed to $\mathrm{Zn}$ and $\mathrm{Cd}$ from destemming-pressing-filtration-bottling stages in Fetească neagră grape variety from Cotnari vine growing region of Romania. Results indicated that heavy metals were linked to diverse $\mathrm{Zn}$ and $\mathrm{Cd}$ sources and complexes during the winemaking processes. Concentration of $\mathrm{Zn}$ and $\mathrm{Cd}$ were generally higher in must than in wine, although heavy metals concentrations were lower than the limits recommended by the International Organization of Vine and Wine for human health safety.
\end{abstract}

\section{Introduction}

Moderate wine consumption may contribute to the daily intake of many metals, including $\mathrm{Cr}, \mathrm{Cd}, \mathrm{Cu}, \mathrm{Fe}$, and $\mathrm{Zn}$. These toxic (heavy metals) are categorised as priority pollutants due to their potential toxic effects if concentrations are not kept under allowable limits. Even if they may not be toxic in the short to medium term, on the long term, heavy metals may pose a cumulative risk especially when the individual has a high exposure to similar compounds from other sources [1].

Concerns about human health impacts under longterm exposure to toxic metals from various beverages and dietary products, including wines, have received increased attention, since wine consumption is common in many areas around the world. Detection of toxic metals in wines is an important and challenging analytical task which requires multi-element methods of good selectivity, sensitivity and robustness. Cd content in wines is influenced by grape variety, environmental factors (soil, climate), and the wine-processing methods [2], whereas $\mathrm{Zn}$ contributes to haze formation and taste defects [3].

Metals may exist in wines in various forms, namely as free ions, or as complexes with organic acids, or as species with large molecules of pectic polysaccharides, peptides, proteins and polyphenols.

The quality, origin, general parameters, aroma characteristics and health safety of wine consumption are influenced by environmental and anthropogenic factors and can be identified by variable contents of inorganic and organic substances forming its chemical composition
$[4,5]$. Environmental factors are represented by geography (region, orography, presence of water resources), climate (temperature, precipitation, humidity, wind, etc.), soil type, soil composition and grape variety [4,5]. Among the anthropogenic factors, negative impacts on wine could be associated with vineyards pollution (soil contamination and irrigation water quality) [6], viticulture management practices such as the use of seed preservatives, chemical sprays, fertilisers, and other grape-growing approaches [7].

In wines, toxic metals concentrations may be influenced by natural sources such as the atmospheric deposition of airborne particulate matter on grapes and transfer of metals from the soil via the roots to the grapes and finally to wine or to possible contaminations during the winemaking process.

Generally, industries, waste management practices, traffic, and even mining operations are among the most severe environmental pollution sources. All these activities may contribute to the introduction of metals into soil, grapes, and ultimately into the final product. Wines produced at vineyards located near industrial areas or close to major highways often contain high levels of $\mathrm{Cd}$ and $\mathrm{Pb}$ due to vehicle exhaust fumes and other emissions to air, water, and/or soil $[8,9]$.

During the winemaking process, heavy metal contamination may be caused by long contact of acidic wine with aluminium, brass, stainless steel, and even wood used in winemaking machinery and pipes, casks, and barrels. The stages during the winemaking process often lead to accumulation of elements as $\mathrm{Al}, \mathrm{Cd}, \mathrm{Cr}, \mathrm{Cu}, \mathrm{Fe}$, and $\mathrm{Zn}$ into the finished wine [10]. 
Moreover, the contamination of wine by metals may occur at different steps of vine-growing $[11,12]$. One key source is the absorption from vineyard soil of $\mathrm{Al}, \mathrm{B}$, $\mathrm{Ba}, \mathrm{Li}, \mathrm{Mg}, \mathrm{Mo}, \mathrm{Si}, \mathrm{Sr}$, Ti. The amount of metal ions transferred into grapes is influenced by the type of soil and the grape absorbance properties. In wines, agrochemical treatments in the vineyard may generate: $\mathrm{Ca}, \mathrm{Cu}, \mathrm{Cd}, \mathrm{K}$, $\mathrm{Mn}, \mathrm{Na}, \mathrm{Pb}, \mathrm{Zn}$, the winemaking equipment may produce $\mathrm{Al}, \mathrm{Cd}, \mathrm{Cr}, \mathrm{Cu}, \mathrm{Fe}, \mathrm{Zn}$ contamination, and so does also the extended contact of wine with winemaking equipment materials (aluminium, brass, glass, stainless steel and wood, etc.). The application of fining agents, such as bentonite, copper sulfate ( $\mathrm{Al}, \mathrm{Ca}, \mathrm{Cd}, \mathrm{Cr}, \mathrm{Cu}, \mathrm{Fe}, \mathrm{Zn}$ ) and other environmental pollution $(\mathrm{Cd}, \mathrm{Co}, \mathrm{Cr}, \mathrm{Hg}, \mathrm{Ni}, \mathrm{Pb}, \mathrm{V})$ may contribute also to wine contamination [13].

In red wines, metals concentrations profile may change during winemaking as a consequence of processes or techniques used. Important impacts on wine metal content have techniques such as filtering, $\mathrm{pH}$ adjustments, yeast hull addition $(\mathrm{Cu}, \mathrm{Fe}, \mathrm{La}, \mathrm{Sb}, \mathrm{U}, \mathrm{V}, \mathrm{Y})$ and bentonite fining $(\mathrm{Ca}, \mathrm{Ce}, \mathrm{Co}, \mathrm{Cr}, \mathrm{Cs}, \mathrm{Cu}, \mathrm{Fe}, \mathrm{Ga}, \mathrm{La}, \mathrm{Li}, \mathrm{Mg}, \mathrm{Mn}, \mathrm{Nd}, \mathrm{Pr}$, $\mathrm{Rb}, \mathrm{Sb}, \mathrm{Sr}, \mathrm{Tl}, \mathrm{U}, \mathrm{V}, \mathrm{Y}, \mathrm{Zn})[14,15]$.

In addition, certain metals have an impact on the organoleptic properties [8] and the description and classification according to the geographical origin or assessment of authenticity [13].

Among the frequently used technologies for wine analysis are atomic and mass spectrometric techniques, such as inductively coupled plasma mass spectrometry, ICP-MS [16,17], inductively coupled plasma optical emission spectrometry, ICP-OES [18], inductively coupled plasma atomic emission spectroscopy, ICP-AES [19], stripping potentiometry, SP [20], flame atomic absorption spectrometry/flame atomic emission spectroscopy, FAAS/FAES [21]. The high-resolution continuum source atomic absorption spectrometry, HR-CSAAS was introduced less than a decade ago and appears to be an alternative method for the identification of metals in wine samples. Important advantages of this method are the possibility of using principal and secondary lines without loss in signal-to-noise ratio (SNR), the choice of the line wings to enhance sensitivity and/or to extend the linear working range [22]. Another major advantage of HRCSAAS is the accessibility to all absorption lines in the 190 to $900 \mathrm{~nm}$ spectral range of the spectrometer [22,23]. As the intensity of the radiation is approximately uniform in the various regions of the UV-Vis spectrum, there are no more lines with low emission intensity. Thus, any secondary line has essentially the same signal-to-noise ratio $(\mathrm{S} / \mathrm{N})$ as the main analytical line and thus it can be used for analytical purposes. With these characteristics, use of a CS allows the possibility of simultaneous multielement determination.

The objective of this study is to quantify metals in different stages of winemaking, namely after destemming, pressing, filtration and bottling stages.

\section{Materials and methods}

\subsection{Winemaking process}

Vitis vinifera cv. Fetească neagră grapes were cultivated in Cotnari (North-East region of Romania) and manually harvested at their optimum point of maturity in good sanitary stage, in 2018.

The grapes were transported in plastic boxes, weighted and evaluated for authenticity and grape variety health.

Around $300 \mathrm{~kg}$ of grapes were vinified in a pilot scale installation at the Department of Viticulture and Oenology, Iasi. The conventional red winemaking method was used. Seven days contact of must with solid parts of grapes was permitted. In the must there were added Zymorouge ${ }^{\circledR}$ EG enzyme, Fermactive ${ }^{\circledR}$ Activateur Plus bio-activator, Fermactive ${ }^{\circledR}$ Rouge Primeur and Fermactive ${ }^{\circledR}$ Activateur Complex yeasts.

After destemming and crushing the grapes, it was added Boise L. Français of tannin. The wine obtained from the press was transferred in vessels for the completion of the alcoholic and malolactic fermentation. After completion of malolactic fermentation, wines were transferred from yeast into new vessels and gelatin and $\mathrm{SO}_{2}$ was added.

Then the wines were filtered through $995 \mathrm{~mm}$ filters, bottled and stored in controlled conditions at $8-10^{\circ} \mathrm{C}$.

Samples were taken from different winemaking stages: destemming, pressing, filtration and bottling stages.

\subsection{Analysis of metals}

Determinations of metals concentrations were carried out in the Department of Environmental Engineering and Management, Iasi, by using a ContrAA $800 \mathrm{G}$ high-resolution continuum source atomic absorption spectrometer (HR-CS AAS) equipped with graphite furnace and hydride technology (HydrEA), from Analytik Jena, Germany (Table 1). A high-resolution spectrometer with CCD detector maps a high-resolution absorption spectrum for every sample and thus permits insights with a hitherto unknown level of detail. The automatic atomizer change and two-dimensional atomizer alignment are also new. The Xenon short arc lamp and a fast high-resolution spectro-meter with $\mathrm{CCD}$ detector, the sample throughput of contrAA ${ }^{\circledR} 800$ for multi-element analyses including screening analysis of unknown samples increases dramatically.

The xenon short-arc lamp, used as a continuum source, provides the possibility to determine almost all known elements in a fast sequential manner with F AAS.

A microwave reaction system, Multiwave Digestion System, Speedwave entry (Berghof, Germany), with rotor for DAP-60K vessel which are made entirely of TFM ${ }^{\mathrm{TM}}$ PTFE was used for the acid digestion of the samples in order to verify the accuracy of the developed method. Ultra-pure water was used in the preparation of standards and digested solutions (Table 2).

In our study, $2.5 \mathrm{~mL}$ of samples were treated with a mixture of $2.5 \mathrm{~mL} \mathrm{HNO}_{3} 65 \%$ (v/v) and $1 \mathrm{~mL} \mathrm{H}_{2} \mathrm{O}_{2} 30 \%$ $(\mathrm{v} / \mathrm{v})$ and heated in a digester block at about $30 \mathrm{~min}$. The resulting solutions were diluted to $50 \mathrm{~mL}$ with purified water. The wavelengths of $\mathrm{Zn}$ and $\mathrm{Cd}$ were $213.857 \mathrm{~nm}$, respectively $228.802 \mathrm{~nm}$.

\subsection{General analysis}

Samples from different stages of winemaking were analyzed for determining the basic parameters according to European and O.I.V. standards. 
Table 1. Graphite furnace programme for determining Zinc and Cadmium in different stages of winemaking.

\begin{tabular}{ccccc}
\hline & $\begin{array}{c}\text { Pyrolysis } \\
\text { temperature/ } \\
{ }^{\circ} \mathrm{C}\end{array}$ & $\begin{array}{c}\text { Atomization } \\
\text { temperature/ } \\
{ }^{\circ} \mathrm{C}\end{array}$ & $\begin{array}{c}\text { Ramp rate for } \\
\text { atomization/ } \\
{ }^{\circ} \mathrm{C}\end{array}$ & $\begin{array}{c}\text { Analyte }- \\
\text { modifier }\end{array}$ \\
\hline $\mathrm{Zn}$ & 300 & 1300 & 1500 & $\begin{array}{c}\text { Without } \\
\text { modifier }\end{array}$ \\
$\mathrm{Cd}$ & 600 & 1200 & 1400 & $\begin{array}{c}\mathrm{NH}_{4} \mathrm{H}_{2} \mathrm{PO}_{4} \\
(1 \%)\end{array}$ \\
\hline
\end{tabular}

Table 2. Microwave digestion system-temperature programme.

\begin{tabular}{lcc}
\hline Step & $\mathbf{1}$ & $\mathbf{2}$ \\
\hline $\mathrm{T}\left({ }^{\circ} \mathrm{C}\right)$ & 140 & 160 \\
$\mathrm{P}($ bar $)$ & 40 & 40 \\
Power $(\%)$ & 70 & 80 \\
Ramp (min) & 5 & 5 \\
Time (min) & 10 & 10 \\
\hline
\end{tabular}

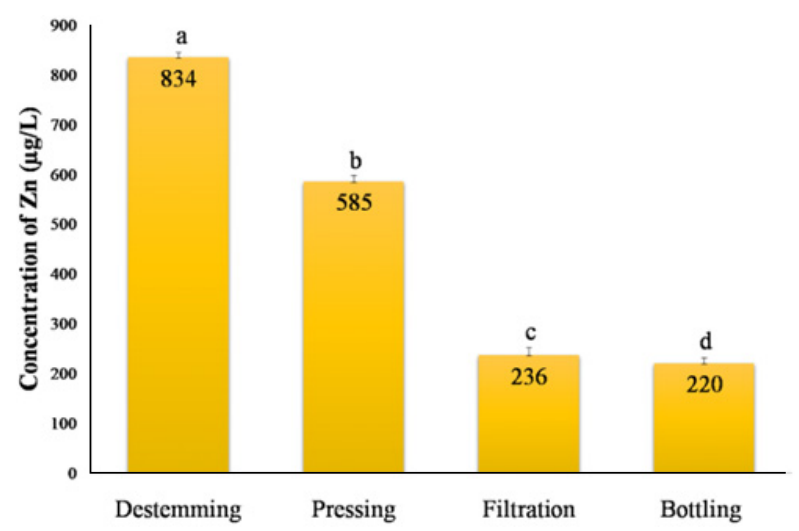

Figure 1. Concentration of $\mathrm{Zn}$ from winemaking stages.

\subsection{Statistical analysis}

All statistical analysis was carried out by Statgraphics Centurion XVI StatPoint Technologies, Inc. (Warrenton, VA, USA). Analyses were performed in triplicate, and the results were expressed as the mean value and the standard deviation.

\section{Results}

From the toxic metals $\mathrm{Zn}$ and $\mathrm{Cd}$ considered for analysis, only $\mathrm{Zn}$ was measurable in the destemming, pressing, filtration and bottling stages of winemaking. $\mathrm{Cd}$ was detected under the limit of quantification (ULOQ) in the Fetească neagră samples analysed in this study, with one exception of the destemming stage where it presented an insignificant concentration value. A high-resolution continuum source atomic absorption spectrometer (HR CS AAS) was used for analysis.

After the pressing stage, Zinc (Zn) concentration decreased with $29.9 \%$, as compared to the destemming stage. $\mathrm{Zn}$ amounts may reduce as insoluble tartrate precipitates are produced in the juice, which would remove the toxic metal from supernatant, as suggested by Pohl [24] and Galani-Nikolakaki [25]. The filtration stage may retain toxic metals or other compounds present in the fermenting wine by using filters with specific porosities.
The systematic removal of metals during fermentation may be attributed to their bounding to the solid components and further elimination of these complexes with the supernatant.

$\mathrm{Zn}$ concentration decreased significantly in wine samples measured after filtration, to more than $71.7 \%$ as compared to the destemming stage. Additional processing and bottling decreased the $\mathrm{Zn}$ content even more to $73.6 \%$ as compared to destemming stage. Determination of toxic metals in wine after bottling is very important in order to evaluate the relevance of oenological products and equipments for the final quality of wines.

The other toxic metal studied in our research was Cd. This was identified only in the destemming stage with a $0.0016 \mu \mathrm{g} / \mathrm{L}$ concentration. In the next stages of winemaking, Cd was below the detection threshold.

A wide variability of these data from Table 3 might result from different factors, both natural and exogenous. Natural aspects include various factors such as soil composition and grape variety. Exogenous factors can be derived from the fermentation process, the winemaking system or from different sources of contamination.

In the literature, higher amounts of $\mathrm{Cd}$ than detected in our study were reported (Table 3). Bimpilas [26] found in Merlot, $8 \mu \mathrm{g} / \mathrm{L}$ of Cd. Lazos and Alexakis [27] reported $\mathrm{Cd}$ levels that ranged from not detectable to $0.03 \mathrm{mg} / \mathrm{L}$ in Greek white and red wine. Furthermore, Cd concentrations higher than the maximum acceptable limit of $0.01 \mathrm{mg} / \mathrm{L}$ were found in wines from Hungary and Serbia. High concentrations of $\mathrm{Cd}$ in Hungarian wines were explained due to the contamination from various containers and during winemaking process.

In the case of wines from Serbia, it was indicated that wineries located near roads or industrial areas where emissions and vehicular discharges are intense, are susceptible to contamination with $\mathrm{Cd}$, while others authors assume that the high $\mathrm{Cd}$ concentration was due to the raw material contamination or irregularities of the technological process of wine production. However, Bentlin [28] found lower concentrations in wine-samples from Chile (from 0.01 to $6 \mu \mathrm{g} / \mathrm{L}$ ), Uruguay (from 0.01 to $0.5 \mu \mathrm{g} / \mathrm{L}$ ), Argentina and Brazil (from 0.01 to $0.06 \mu \mathrm{g} / \mathrm{L}$ ).

It is also known that the presence of $\mathrm{Cd}$ in wine may be directly associated with air pollution and the use of phytosanitary products, which contained salts of this metal [29].

Fining agents such as bentonite, gelatine, isinglass, PVPP, carrageenan, silica, etc., are frequently used in winemaking. It has been reported that some winemaking treatments, especially bentonites and yeast hulls can affect the metals and the composition of wine. Bentonite is a clay mineral based on montmorillonite, as welling clay mineral, with a negative surface charge and a high surface area. It is available in either $\mathrm{Ca}^{2+}$ or $\mathrm{Na}^{+}$forms, usually the latter. The efficiency of the process is subject to the presence of competing cations $\left(\mathrm{K}^{+}, \mathrm{N}^{+}, \mathrm{Ca}^{2+}\right.$ and $\left.\mathrm{H}^{+}\right)$.

Bentonite, which mostly consists of montmorillonite type phyllosilicate, acts as a settling aid to clarify wine and to remove amino acids, minerals, polyphenols, and protein, thus minimizing the risk of haze formation in wine. Proteins are depleted in wines due to their adsorption on the surface of the silica layers. Yeast hulls, living and nonliving biomass of Saccharomyces cerevisiae, have also been reported to significantly lower heavy metal content of 
Table 3. Concentration of $\mathrm{Zn}$ and $\mathrm{Cd}$ in wines from various country.

\begin{tabular}{|c|c|c|c|c|c|}
\hline Origin & $\begin{array}{l}\text { Analytical } \\
\text { technique }\end{array}$ & $\begin{array}{l}\text { Type of } \\
\text { wines }\end{array}$ & $\begin{array}{c}\mathrm{Zn} \\
(\mu \mathrm{g} / \mathrm{L})\end{array}$ & $\begin{array}{c}\mathrm{Cd} \\
(\mu \mathrm{g} / \mathrm{L})\end{array}$ & References \\
\hline \multirow[b]{2}{*}{ Turkish } & \multirow[b]{2}{*}{ ET AAS } & Merlot & 490 & 7.20 & \multirow[b]{2}{*}[32]{} \\
\hline & & Shiraz & 595 & ULOQ & \\
\hline \multirow{2}{*}{ Greece } & ICP-OES & Merlot & 978 & 8 & \multirow[b]{2}{*}{ [26] } \\
\hline & ICP-MS & Shiraz & 652 & 7 & \\
\hline Romania & HR-CS AAS & Fetească neagră & 220 & ULOQ & This study \\
\hline \multirow{2}{*}{ Argentina } & ETAAS & White wines & 95 & 1.2 & \multirow[b]{2}{*}{ [8] } \\
\hline & USN-ICP-OES & Red wines & 110 & 3.6 & \\
\hline \multirow{4}{*}{ Italy } & \multirow{2}{*}{$\mathrm{ICP}$} & Merlot Trentino & 732 & 0.66 & \multirow{4}{*}{ [33] } \\
\hline & & Primitivo Puglia & 541 & 0.25 & \\
\hline & \multirow{2}{*}{ SV } & Merlot Trentino & 710 & 0.64 & \\
\hline & & Primitivo Puglia & 540 & 0.26 & \\
\hline
\end{tabular}

ULOQ: under the limit of quantification.

Table 4. General parameters from different stages of winemaking.

\begin{tabular}{|l|c|c|c|c|c|c|c|c|c|}
\hline & pH & TA & VA & Malic Acid & Lactic Acid & Total Sugar & Ethanol & ${\text { Free } \mathbf{S O}_{2}}$ & Total SO$_{\mathbf{2}}$ \\
\hline Destemming & $3.39 \pm 0.02$ & $4.5 \pm 0.03$ & $0.31 \pm 0.001$ & $5.1 \pm 0.03$ & $0.0 \pm 0.00$ & $0.3 \pm 0.001$ & $0.9 \pm 0.002$ & $10 \pm 0.05$ & $25 \pm 0.02$ \\
\hline Pressing & $3.70 \pm 0.01$ & $4.2 \pm 0.01$ & $0.35 \pm 0.002$ & $3.8 \pm 0.02$ & $0.0 \pm 0.00$ & $1.1 \pm 0.001$ & $12.2 \pm 0.03$ & $15 \pm 0.07$ & $32 \pm 0.09$ \\
\hline Filtration & $3.91 \pm 0.01$ & $3.6 \pm 0.02$ & $0.43 \pm 0.001$ & $0.6 \pm 0.02$ & $2.9 \pm 0.02$ & $1.4 \pm 0.002$ & $12.4 \pm 0.04$ & $25 \pm 0.03$ & $56 \pm 0.04$ \\
\hline Bottling & $3.95 \pm 0.02$ & $3.0 \pm 0.01$ & $0.46 \pm 0.001$ & $0.2 \pm 0.01$ & $3.2 \pm 0.01$ & $1.7 \pm 0.003$ & $12.7 \pm 0.03$ & $33 \pm 0.08$ & $61 \pm 0.07$ \\
\hline
\end{tabular}

Note: TA-total acidity (g tartaric acid/L); VA-volatile acidity (g acetic acid/L); malic acid (g/L); lactic acid (g/L); total sugar $(\mathrm{g} / \mathrm{L})$, ethanol $(\% \mathrm{v} / \mathrm{v})$, free and total SO 2 (mg/L).

wines by biosorption. Nicolini [30] studied the changes in metals element composition resulting from Italian wines treated with 10 different types of bentonite and two different yeast hulls. The authors found that bentonite fining significantly lowered concentrations of $\mathrm{K}, \mathrm{Cu}, \mathrm{Rb}$, and $\mathrm{Zn}[30]$.

After bottling, the concentrations of $\mathrm{Cd}$ and $\mathrm{Zn}$ were below the maximum acceptable limits for toxic metals in wine as outlined by The International Organisation of Vine and Wine (OIV) [31].

The concentrations of $\mathrm{Zn}$ and $\mathrm{Cd}$ from different winemaking stages detected in our study do not constitute any imminent toxicological risk when considering consumers'average consumption of wine. Nevertheless, periodic monitoring is important to protect and prevent potential health risks associated with excessive wine consumption. As an essential element, Zn plays a major role in plant growth, and its traces are naturally present in wine. Higher concentrations can have negative effect on sensory characteristics of wine. Maximum acceptable concentration limits of $\mathrm{Zn}$ and $\mathrm{Cd}$ in wine is set to $5 \mathrm{mg} / \mathrm{L}$, respectively $0.01 \mathrm{mg} / \mathrm{Land}$ none of the studied wines samples exceeded this limit.

The general characteristics of these four stages from winemaking were analysed: $\mathrm{pH}$, total and volatile acidity, total sugar, ethanol, malic and lactic acid, free and total $\mathrm{SO}_{2}$ (Table 4).

A dendogram analysis allowed to distinguish clusters formed by destemming and pressing stages from another cluster comprising filtration and bottling stages (Fig. 2).

\section{Conclusions}

Chemicals used in viticulture, oenological products, equipments, environmental contamination, and poor cellar practice are the key factors which influence the toxic metal concentrations in wine. The metals content in wine

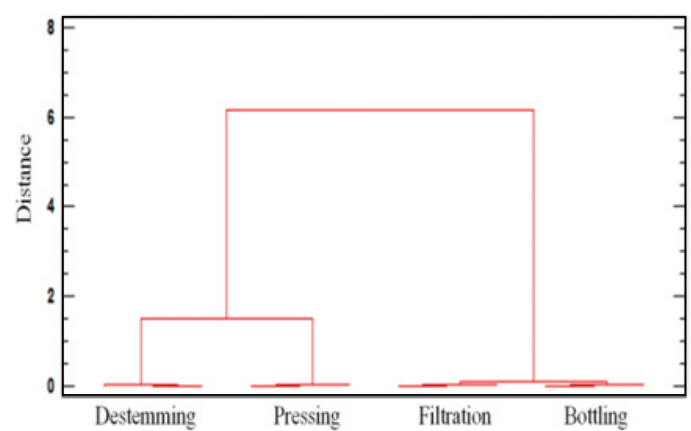

Figure 2. Cluster analyses based on the general parameters from the winemaking stages.

differs between countries, thus suggesting that winemakers should be more aware of possible contaminations with toxic metals.

Our study reveals new insights on toxic metals presence in different winemaking stages. We noticed that technological processes are crucial for significant decreases of metal content in wines.

Moderate consumption of wine may contribute to a healthy lifestyle. As long as the wine consumption is kept under moderate limits, no risks to an excessive exposure to toxic metals are present. Future studies are necessary to evaluate other toxic metals and the influence of winemaking stages for the overall wine safety and quality.

This study was supported by a grant of Ministry of Research and Innovation, CNCS - UEFISCDI, project number PN-III-P11.1-PD-2016-0325, "Environmental and human related impacts and risks of toxic compounds in the winemaking process" within PNCDI III. 


\section{References}

[1] V. Geissen, H. Mol, E. Klumpp, G. Umlauf, M. Nadal, M. van der Ploeg, M., S.E.A.T.M. van de Zee, C.J. Ritsema, J. Soil Water Conserv. 3, 57 (2015)

[2] K. Pyrzynska, Crit. Rev. Anal. Chem. 34, 69 (2004)

[3] K.A. Riganakos, P.G. Veltsistas, Food Chem. 82, 637 (2003)

[4] Z. Fiket, N. Mikac, G. Kniewald, Food Chem. 126, 941 (2011)

[5] D. Kostic, S. Mitic, G. Miletic, S. Despotovic, A. Zarubica, A. J. Serb, Chem. Soc. 75, 1701 (2010)

[6] D. Fernandez-Calvino, J.A. Rodriguez-Suavez, E. Lopez-Periago, M. Arias-Estevez, J. Gandara, Geoderma. 145, 91 (2008)

[7] V. Chaignon, I. Sanchez-Neira, P. Herrmann, B. Jaillard, P. Hinsinger, Environ. Pollut. 123, 229 (2003)

[8] R. Lara, S. Cerutti, J.A. Salonia, R.A. Olsina, L.D. Martinez, Food Chem. Toxicol. 43, 293 (2005)

[9] J. Cvetkovic, S. Arpadjan, I. Karadjova, T. Stafilov, Acta Pharm. 56, 69 (2006)

[10] P. Kment, M. Mihaljevič, V. Ettler, O. Šebek, L. Strnad, L. Rohlová, Food Chem. 91, 157 (2005)

[11] F. Al Nasir, A.G. Jiries, M.L. Batarseh, F. Beese, Enviro. Moni. Assess. 66, 253 (2001)

[12] L. La Pera, G. Dugo, R. Rando, G.D. Bella, R. Maisaho, F. Salvo, Food Addit. Contam. Part A Chem. Anal. Control Expo. Risk. Assess. 25, 302 (2008)

[13] B. Tariba, Biol Trace Elem Res. 144, 143 (2011)

[14] G. Nicolini, R. Larcher, P. Pangrazzi, L. Bontempo, Vitis. 43, 41 (2004)

[15] M. del Castineira Gomez, R. Brandt, N. Jakubowski, J.T. Andersson, J. Agric. Food Chem. 52, 2953 (2004)

[16] E.P. Pérez-Álvarez, R. Garcia, P. Barrulas, C. Dias, M.J. Cabrita, T. Garde-Cerdán, Food Chem. 270, 273 (2019)
[17] I. Geana, A. Iordache, R. Ionete, A. Marinescu, A. Ranca, M. Culea, Food Chem. 138, 1125 (2013)

[18] P. Paneque, M.L. Morales, P. Burgos, L. Ponce, R.M. Callej, Food Control 75, 203 (2017)

[19] M. Aceto, O. Abollino, M.C. Buzzoniti, E. Mentasti, C. Sarzanini and M. Malandrio, Food Addit. Contam. 19, 126 (2002)

[20] A.C. Clark, N. Kontoudakis, C. Barril, L.M. Schmidtke, G.R. Scollary, Talanta 154, 431 (2016)

[21] P. Pohl, M. Kalinka, M. Piepr, Microchem. J. 147, 538 (2019)

[22] B. Welz, H. Becker-Ross, S. Florek, U. Heitmann, Wiley-VCH, Weinheim (2005)

[23] B. Welz, S. Morés, E. Carasek, M.G.R. Vale, M. Okruss, H. Becker-Ross, Appl. Spectrosc. Rev. 45, $327(2010)$

[24] P. Pohl, TrAC 26, 941 (2007)

[25] S. Galani-Nikolakaki, N. Kallithrakas-Kontos, A.A. Katsanos, Sci. Total Enviro. 285, 155 (2002)

[26] A. Bimpilas, D. Tsimogiannis, K. Balta-Brouma, T. Lymperopoulou, V. Oreopoulou, Food Chem. 178, 164 (2015)

[27] E.S. Lazos, A. Alexakis, Int. J. Food. Sci. Techno. 24, 39 (1989)

[28] F.R.S. Bentlin, F.H. Pulgati, V.L. Dresslerc, D. Pozebon, J. Braz. Chem. Soc. 22, 327 (2011)

[29] C.M. Almeida, M.T. Vasconcelos, J. Agric. Food Chem. 51, 4788 (2003)

[30] G. Nicolini, R. Larcher, P. Pangrazzi, L. Bontempo, Vitis-J. Grapevine Res. 43, 41 (2015)

[31] Organisation Internationale de la Vigne et du vin (OIV). International Code of Oenological Practices, Annex: Maximum Acceptable Limits; Issue 2015/01 (OIV: Paris, France, 2015)

[32] I.M. Alkis, S. Oz, A. Atakol, N. Yilmaz, R. Ertan Anli, O. Atakol, J. Food Compost. Anal. 33, 105 (2014)

[33] Kh.Z. Brainina, N. Yu. Stozhko, G.M. Belysheva, O.V. Inzhevatova, L.I. Kolyadina, C. Cremisini, M. Galletti, Anal. Chim. Acta 514, 227 (2004) 